\title{
SELF-SIMILARITY OF WIND PROFILES IN BLOWING SNOW ALLOWS OUTDOOR MODELING
}

\author{
By Ronald D. TAbler \\ (Rocky Mountain Forest and Range Experiment Station, U.S. Department of Agriculture \\ Forest Service, Laramie, Wyoming 82070, U.S.A.)
}

\begin{abstract}
Drifts formed by snow fences appear to be scaled in proportion to fence height over a height range of nearly two orders of magnitude. This paper examines natural scaling in terms of commonly accepted similitude criteria. It is suggested that requirements for dynamic similarity of flow fields are satisfied over a period of time because surface roughness height $z_{0}$ varies approximately as the square of shear velocity $u_{*}^{2}$ for saltating flows in air. This is demonstrated by intensive measurements of wind profiles over snow and ice surfaces. Satisfaction of similitude requirements for scaling particle motion is less certain, although natural sorting may effectively scale particles over a restricted range of wind speeds. Natural scaling of drifts suggests snow erosion and deposition can be studied with reduced-scale models on smooth surfaces outdoors. The feasibility of this technique is demonstrated by results from I : 30 scale models of $\mathrm{I} .8$ and $3.8 \mathrm{~m}$ snow fences on both level lake ice and irregular terrain constructed from compacted snow.
\end{abstract}

RÉsumÉ. L'auto-similitude des profils de congères de neige souffée. Les congères formées par les barrières à neige semblant être dimensionnées proportionnellement à la hauteur de la barrière sur une large gamme de hauteurs s'étalant sur près de deux ordres de grandeur. Cet article examine les dimensions observées d'après les critères de similitude généralement admis. On fait l'hypothèse que les exigences pour une similitude dynamique sont satisfaites sur une période de temps puisque la hauteur $z_{0}$ de la rugosité de surface varie approximativement comme le carré de la vitesse de cisaillement $u_{*}^{2}$ de l'écoulement de saltation dans l'air. Ceci est démontré par de nombreuses mesures de profils de vent sur les surfaces de neige et glace. La satisfaction des exigences de la similitude pour les paramètres du mouvement des particules est moins évidente, bien qu'un tri naturel puisse effectivement déterminer la taille des particules dans une gamme restreinte de vitesses de vent. Le dimensionnement naturel des congères fait penser que l'érosion et le dépôt de la neige peut être étudié sur modèle réduit sur des surfaces lisses en plein air. La "faisabilité" de cette technique est démontrée par les résultats obtenus sur des modèles au $\mathrm{r} / 30$ de barrières à neige de $\mathrm{I}, 8$ et $3,8 \mathrm{~m}$ installées d'une part sur de la glace de lac horizontale et d'autre part sur neige compactée en terrain irrégulier.

Zusammenfassung. Die Selbst-Entsprechung von Windprofilen in driftendem Schnee. Die Dimensionen von Driftablagerungen an Schneezäunen scheinen in Proportion zur Zaunhöhe zu stehen, und zwar über einen Höhenbereich von fast zwei Grössenordnungen. Diese Arbeit untersucht die Möglichkeit von Modellversuchen in der freien Natur unter Berücksichtigung der gewöhnlich als gültig angenommenen Ähnlichkeitskriterien. Es wird angenommen, dass die Voraussetzungen für die dynamische Ähnlichkeit von Stromfeldern über einen längeren Zeitabschnitt erfüllt sind, da die Höhe der Oberflächenrauhigkeit $z_{0}$ sich annähernd mit dem Quadrat der Schergeschwindigkeit $u_{\star}^{2}$ für sprungveise Transport ändert. Dies wird durch intensive Messungen von Windprofilen über Schnee- und Eisflächen gezeigt. Die Erfüllung der Ähnlichkeitsforderungen bei Modellversuchen zur Bewegung von Teilchen ist weniger gesichert, obwohl die natürliche Sortierung den Grössenbereich der Teilchen über einen beschränkten Bereich von Windgeschwindigkeiten wirksam imitieren dürfte. Die natürliche Driftbemessung lässt erwarten, dass Schneeerosion und -ablagerung mit masstäblich verkleinerten Modellen auf glatten Oberflächen im Freien untersucht werden kann. Die Anwendbarkeit dieser Technik wird durch Ergebnisse an Modellen von $\mathrm{I}, 8$ und 3,8 $\mathrm{m}$ hohen Schneezäunen im Masstab I : 30 sowohl über ebenem Seeeis wie über unregelmässigem Gelände, hergestellt aus kompaktem
Schnee, erwiesen.

\section{INTRODUCTION}

"Similarity of flow phenomena not only occurs between a prototype and its model but also may exist between various natural phenomena if certain laws of similarity are satisfied" (Vennard, 1954).

Studies of drifts formed by snow fences and other objects indicate that drift geometry is scaled to barrier height for heights from 0.8 to $4 \mathrm{~m}$ (Tabler, 1980) and this leads one to consider the use of reduced-scale models outdoors in the study of snow deposition and erosion. This technique could circumvent many of the well-known problems associated with simulating snow in wind-tunnel and water-flume modeling.

In attempting to explain proportionality of snow-drifts in terms of commonly accepted similitude requirements, it became apparent that wind profiles under conditions of blowing snow are essentially "self-similar". "Self-similarity" is said to exist if similitude requirements 
are met simultaneously between two parts of the same flow field, or if similitude exists between complete flow patterns at two different times (Holt, I96I).

The field measurements of wind profiles and small-scale drifts reported in this paper support the hypothesis of self-similarity for saltation flows in air, and demonstrate the possibility for outdoor model studies.

\section{Similitude REQUiREMENTS}

In this section, an attempt will be made to show how similitude requirements for modeling blowing snow might be fulfilled under natural conditions.

For true, quantitative scaling of erosion and deposition features associated with windtransported snow, models must be scaled to ensure geometric, kinematic, and dynamic similitude. Geometric similarity exists if all dimensions of the model are geometrically scaled with the prototype, so that model and prototype have the same shape. Kinematic similarity requires ratios of all corresponding velocities and accelerations to be the same throughout the flow, and dynamic similarity requires ratios of all pertinent forces to be matched. These requirements are described in the classical presentation by Langhaar (I95I).

Simulation of snow transport, erosion, and deposition phenomena also requires scaling of particle trajectories and snow concentration profiles. The physical processes involved are complex, and it is not yet possible to specify on theoretical grounds the necessary and sufficient scaling requirements. A variety of scaling criteria have been proposed in the literature, most of which have been derived from the equations of motion for saltating or "suspended" particles. Recent assessments of similitude requirements for modeling snow transport include those by Mellor (1965), Odar (1965), Dyunin (1967), Calkins (1975), Kind (1976), Wuebben (1978), and Iversen (1979, I980). We will now see how some of the more generally recognized criteria may be met under natural conditions.

\section{Requirements for similarity of wind profiles}

The wind profile for fully rough, turbulent flow with neutral stability is given by

$$
u / u_{*}=2.5 \ln \left(z / z_{0}\right), \quad z \geqslant z_{0},
$$

where $u$ is mean horizontal wind speed at height $z$ above the surface, $z_{0}$ is the roughness height ( $z$ at $u=0$ ), $u_{*}$ is the shear velocity $\left(u_{*} \equiv \sqrt{ }(\tau / \rho)\right.$, where $\tau$ is shear stress and $\rho$ is air density), and the coefficient 2.5 is the reciprocal of von Kármán's constant, here assumed to be 0.4 . Measurements by Budd and others (I966) and Liljequist (I957) demonstrate convincingly that Equation ( $\mathrm{I}$ ) adequately describes the wind profile at heights greater than $5 \mathrm{~cm}$ under blowing snow conditions. A basic premise developed in the following discussion is that the saltation layer allows surface roughness to vary as the square of shear velocity, providing a mechanism for self-similarity of wind profiles.

For saltating flows, $z_{0}$ cannot be interpreted as the true physical height at which $u=0$, but rather as an index to effective surface roughness. Zingg's (1953) wind-speed measurements within the saltation layer in blowing sand suggested a departure from the logarithmic profile below the $1 \mathrm{~cm}$ height, with measured velocities significantly greater than downward extrapolation of the upper profile would predict. Zingg attributed this to momentum transfer by saltating particles.

The basic requirement for dynamic similarity, with or without snow transport, is that of matching of the Froude numbers (ratio of inertial and gravitational forces), so that

$$
\left(U^{2} / L g\right)_{\mathrm{m}}=\left(U^{2} / L g\right)_{\mathrm{p}},
$$

where $U$ is a reference velocity for the flow field, $g$ is gravitational acceleration, $L$ is the 
characteristic reference length, or dimension, used to define the geometric scale, and subscripts $m$ and $p$ refer to model and prototype values, respectively.

For flows transporting solid particles, the "densimetric" Froude number (Wuebben, I978) is usually substituted for Equation (2) to account for possible differences in the ratio of particle-fluid densities. For the natural conditions under consideration, the densimetric Froude number reduces to Equation (2), and $g$ is essentially the same in model and prototype, so that the scaling ratio becomes

$$
L_{\mathrm{m}} / L_{\mathrm{p}}=U_{\mathrm{m}^{2}} / U_{\mathrm{p}^{2}} .
$$

For model and prototype flows to have kinematic similarity, both roughness heights $z_{0}$ and shear velocities $u_{*}$ in Equation (I) must be scaled so that

$$
L_{\mathrm{m}} / L_{\mathrm{p}}=U_{\mathrm{m}^{2}} / U_{\mathrm{p}^{2}}=\left(u_{*}\right)_{\mathrm{m}}^{2} /\left(u_{*}\right)_{\mathrm{p}}{ }^{2}=\left(z_{0}\right)_{\mathrm{m}} /\left(z_{0}\right)_{\mathrm{p}} .
$$

Over natural surfaces composed of rigid roughness elements, $z_{0}$ is essentially independent of wind speed for fully rough flow (Sutton, I953, p. 233), so that two wind profiles over the same surface cannot be exactly scaled both kinematically and dynamically, although similitude requirements may be approximately met over a wide range of heights and wind speeds. For the case of blowing snow or sand, however, the requirements of Equation (4) are more closely met because $z_{0}$ increases with wind speed as a result of the surface roughness generated by the saltating particles. Bagnold (I94I) showed that the fluid momentum loss associated with saltating particles was proportional to $u_{*}{ }^{2}$, and Owen (1964) reasoned that since maximum particle trajectory height is approximately proportional to $u_{*}^{2}, z_{0}$ should also vary as the square of shear velocity. Letting $A$ represent the coefficient of proportionality and substituting $A u_{*}^{2}$ for $z_{0}$, Equation (I) can be written

$$
u / u_{*}=2.5 \ln \left(2 g z / u_{*}^{2}\right)+D,
$$

where

$$
D=-2.5 \ln (2 g A) \text {. }
$$

Owen empirically determined $D$ to be $9 \cdot 7$, a value based on published data for sand and soil transport.

Radok (I968) was the first to recognize the significance of Owen's hypothesis for snow transport phenomena, and he effectively demonstrated the existence of self-similarity using the Byrd Station data. Kind ( 1976 ) later showed Ōura's data for blowing snow to be in general agreement with Equation ( $5 \mathrm{a}$ ) and Owen's value for $D$.

Although differences of opinion may exist regarding Owen's assumptions in deriving Equation ( $5 \mathrm{a}$ ), particularly with respect to the importance of rotation-induced lift of saltating particles (White and Schulz, I977), empirical evidence suggests roughness height is at least approximately proportional to the square of shear velocity for fully rough, saltating flows. Although it can be argued that the range of $u_{*}$ for published data is too restricted to provide a conclusive empirical test of the functional form (a linear relationship fits the author's data nearly as well), it suffices to note that the variation of $z_{0}$ with $u_{*}$ is sufficient to meet similitude requirements of Equation (4), helping to explain why snow-drifts behind objects are scaled in proportion to object height. As an example, flow past a snow fence $\mathrm{I} m$ in height in a wind with $u_{*}=25 \mathrm{~cm} / \mathrm{s}$ (the approximate threshold for movement of fresh snow particles) would be similar to that past a $4 \mathrm{~m}$ fence at $u_{*}=50 \mathrm{~cm} / \mathrm{s}$, or a $10 \mathrm{~m}$ fence at $u_{*}=79 \mathrm{~cm} / \mathrm{s}$, provided, of course, that the fences were geometrically scaled in all dimensions.

The similitude requirements of Equation (4) obviously cannot be met instantaneously, but a range of heights would be effectively scaled over a period of time which would depend on the variation in wind speed. A wind characterized by a mean $10 \mathrm{~m}$ speed of $\mathrm{I} 6 \mathrm{~m} / \mathrm{s}$ and a $50 \%$ gust factor, for example, would vary from 8 to $24 \mathrm{~m} / \mathrm{s}$ over a period of five minutes, implying a natural scaling range of nearly one order of magnitude. 


\section{Scaling of particle trajectories}

Dyunin ( 1967 ) states that, although it is possible to simulate fully-developed drift shapes without meeting all particle scaling criteria, modeling the dynamics of snow deposition such as accumulation rates and pre-equilibrium drift shapes requires scaling of particle trajectories (and thus scaling of snow concentration profiles).

It appears difficult to specify realistic similitude criteria because of the wide range of natural surface conditions that are known to exist, and also because so little is actually known about the size distribution, interparticle forces, mechanics of detachment, and trajectories of snow particles. As a result, cohesive (bonding) forces have not been considered in published assessments of modeling criteria. Schmidt (1980) has shown that interparticle forces cannot be dismissed as negligible. His calculations indicate, for example, that cohesive forces are so much greater than particle weights that impact threshold shear velocity, as defined by Bagnold (I94I), is nearly independent of particle diameter. Although criteria for modeling non-cohesive particles are thus of questionable applicability for the case of snow transport, for completeness we will briefly discuss their inferences for natural dynamic scaling.

To simulate particle trajectories either explicitly or implicitly, it is generally agreed that $W / U$ and $u_{* \mathrm{i}} / U$ must be matched, where $W$ is the particle terminal velocity and $u_{* \mathrm{i}}$ is the impact threshold shear velocity required to sustain particle motion (Kind, 1976). It has been argued that for non-cohesive particles, these requirements should be sufficient and they imply the necessary scaling for particle diameter. Intuitively, it is easy to visualize a natural mechanism that might allow these conditions to be met for the case of a non-uniform distribution of particle sizes, such as exists for blowing snow. At moderate wind speeds, a natural sorting takes place such that the predominant size of saltating particles is determined by the prevailing shear stress. This process is particularly evident when migrating snow ridges or dunes form under conditions of relatively low wind speeds and aged snow, resulting in a continuous sorting process as coarse grains are forced up the windward side by the impact of smaller saltating grains.

For a non-uniform distribution of particle sizes, it would seem reasonable to replace $u_{* i}$ with an analogous term for the maximum particle diameter entering saltation $u_{* \mathrm{~s}}$. $u_{* \mathrm{~s}}$ can vary with $u_{*}$ only over the range of available particle sizes, and the domain in which $u_{* \mathrm{~s}} / u_{*}$ values are matched is thus determined by the relationship between $u_{* s}$ and particle diameter. For conditions of fully rough flow, Bagnold (I94I), Zingg (1953), and others have found $u_{* i} \propto \sqrt{ } d$. As has already been pointed out, this may not be true for bonded particles and it is uncertain if a similar relationship would exist for $u_{* \mathrm{~s}}$.

Particles smaller than a certain limit might be expected to become suspended in the air flow and not exhibit characteristic saltation trajectories. Iversen (1979) proposes this limit as that where $W=u_{* i}$, which the author has calculated from Iversen's equations to be about $70 \mu \mathrm{m}$, for snow particles. This order is substantiated by the distribution of particle sizes at $3 \mathrm{~cm}$ above the snow surface reported by Budd (1966), which shows an absence of particles smaller than about $75 \mu \mathrm{m}$, with about $95 \%$ of the particles between 100 and $300 \mu \mathrm{m}$. Since $W$ is approximately proportional to diameter over the range 100 to $\mathrm{I}$ ooo $\mu \mathrm{m}$, if $u_{* \mathrm{~s}}$ were proportional to the square root of particle diameter, the $W / u_{*}$ ratios would not be scaled. Budd's (I966) data indicated, however, that the relationship between $W$ and the ro $m$ wind speed is nearly linear at heights close to the surface, suggesting similarity requirements for terminal velocity may be essentially fulfilled under natural conditions.

Given the presence of saltating particles, White and Schulz (1977) maintain that it is reasonable to assume fully rough flow even though roughness Reynolds numbers fall in the transition regime as defined by commonly used criteria (Sutton, I953):

Smooth flow: $\quad \frac{u_{*} k}{\nu}<5.5$, 


$$
\frac{u_{*} z_{0}}{\nu}<0.13
$$

Fully rough flow:

$$
\begin{aligned}
& \frac{u_{*} k}{v}>75, \\
& \frac{u_{*} z_{0}}{v}>2.5,
\end{aligned}
$$

where $k$ is the effective height of the surface roughness elements and $\nu$ is kinematic viscosity. These limits are not clearly defined, however, and Kind (1976) concludes that viscosity effects should be small in saltation flows provided

$$
\frac{u_{*}^{3}}{2 g_{\nu}}>30 \text {. }
$$

This condition, which Kind proposes as a modeling requirement, is met if $u_{*}$ is at and above threshold values observed in the field $(\geqslant 23 \mathrm{~cm} / \mathrm{s})$.

In summary, all requirements appear to be met for the self-similarity of wind profiles during snow transport. The scaling of particle trajectories is much less certain, but may be at least partially accomplished through natural sorting processes over the range of the wind speeds associated with migrating snow ridges or dunes. Although additional study will be needed to evaluate requirements for particle scaling, an obvious argument for self-similiarity of concentration profiles can be based on the observation that mass flux of blowing snow in the first $2 \mathrm{~m}$ above the surface is proportional to $U^{3}$ (Dyunin, 1954; Kobayashi, 1970). Snow concentration would therefore be proportional to $U^{2}$, implying concentration profiles in the lower layers would be scaled given the requirements of Equation (4).

\section{Field experiments}

Wind profiles were measured over a frozen lake during a continuous study from 27 December 1978 to 16 February 1979 in order to test the hypothesis that $z_{0}$ varies with $u_{*}^{2}$ so as to provide natural dynamic scaling of wind profiles under blowing snow conditions.

Snow accumulation behind $\mathrm{r} / 30$ scale models of $\mathrm{r} .8$ and $3.8 \mathrm{~m}$ snow fences was measured under several conditions to provide additional tests of natural scaling, to confirm modeling criteria, and to demonstrate the feasibility of outdoor modeling. These models were run on flat lake ice, as well as on scaled "terrain" constructed from compacted snow.

\section{Study area}

All studies were conducted at Diamond Lake in south-east Wyoming at lat. $4 \mathrm{I}^{\circ} 37^{\prime} \mathrm{N}$., long. $106^{\circ} \mathrm{of}^{\prime} \mathrm{W}$., and elevation $2240 \mathrm{~m}$. The lake is $80 \mathrm{ob}\left(800000 \mathrm{~m}^{2}\right)$ in area and is surrounded by gently rolling hills covered with low-growing brush and grass. The site was selected for its wind and uniform up-wind terrain; it lies about $\mathrm{ro} \mathrm{km}$ down-wind from the foothills of a 3 ooo to $3700 \mathrm{~m}$ mountain range. Air temperatures during the study ranged from o to $-40^{\circ} \mathrm{C}$ and averaged about $-10^{\circ} \mathrm{C}$ during periods of blowing snow.

The portable mast supporting the sensors was located $380 \mathrm{~m}$ from the up-wind shore in the direction of the prevailing wind.

\section{Instrumentation}

Cup-type a.c. generating anemometers, constructed of a light-weight high-impact plastic, were installed at heights about I0, 20, 40, 80, I6o, 320,500, and $\mathrm{I} 000 \mathrm{~cm}$ above the ice surface. Both the output frequency and amplitude of these instruments are linearly related to wind speed, with $60 \mathrm{~Hz}$ corresponding to $45.8 \mathrm{~m} / \mathrm{s}$. The swept diameter of the rotor is $19 \mathrm{~cm}$, threshold wind speed is about $\mathrm{I} \mathrm{m} / \mathrm{s}$, and dynamic response is o to $18 \mathrm{~m} / \mathrm{s}$ in $0.45 \mathrm{~s}$. 
Multiplexed counting circuits, designed by Dr R. A. Schmidt, were used to measure mean frequency output simultaneously from the eight anemometers. Thermistor temperature sensors, calibrated to within approximately $\pm 0.02 \mathrm{deg}$, were also installed at each anemometer level.

An electronic calculator with a 23 kbyte memory served as the system controller for data acquisition and also permitted on-line analysis of wind and temperature profiles so that any changes could be correlated with visual observation of surface conditions. Data were also recorded on a magnetic disk. Other components of the calculator-controlled system included an $X-Y$ plotter, impact printer, digital voltmeter, and clock. This equipment was housed in a van parked on the lake shore about $150 \mathrm{~m}$ from the mast, in a direction perpendicular to the prevailing wind.

The basic counting interval for wind-speed measurement was $5 \mathrm{~min}$, and all data presented here are five-minute averages. The accumulation of counts over several successive intervals did not significantly reduce the sums of squares of deviations from fitted profiles.

The large number of profiles collected (I 579) allowed us to restrict analyses reported in this paper to conditions of neutral stability where diabatic corrections were not required.

Displacement heights were determined using the method proposed by Stearns (1970), but inclusion of this parameter in the logarithmic profile equation significantly increased the variance in the relationship between $z_{0}$ and $u_{*}$ without significantly changing regression estimates. Since it was usually possible to measure instrument heights accurately on the lake surface, the displacement height was assumed equal to zero in the analyses reported here.

\section{Models}

The snow-fence design modeled in these experiments was that of the Wyoming Highway Department standard design described by Tabler (1974). Prototype dimensions include $2.5 \mathrm{~cm}$ thick by $\mathrm{I} 5 \mathrm{~cm}$ wide horizontal slats separated by $\mathrm{I} 5 \mathrm{~cm}$ spaces, a bottom gap of approximately o. I $H$ (where $H$ is vertical fence height), a $15^{\circ}$ inclination down-wind, and a $5 \mathrm{~m}$ panel length.

Models of these fences were constructed from copper-sheathed printed-circuit board or balsa wood, to about a I/30 scale (Fig. I). Actual models of heights 5.5 and $12.4 \mathrm{~cm}$ were scaled in all dimensions to their $\mathrm{r} .8$ and $3.8 \mathrm{~m}$ prototypes. Magnetic strips glued to the base of the models were used to fasten them to thin steel plates placed on the ice. All models were at least $30 \mathrm{H}$ in length to ensure the absence of end-effects in the center of the drift where depths were measured (Tabler, r974).

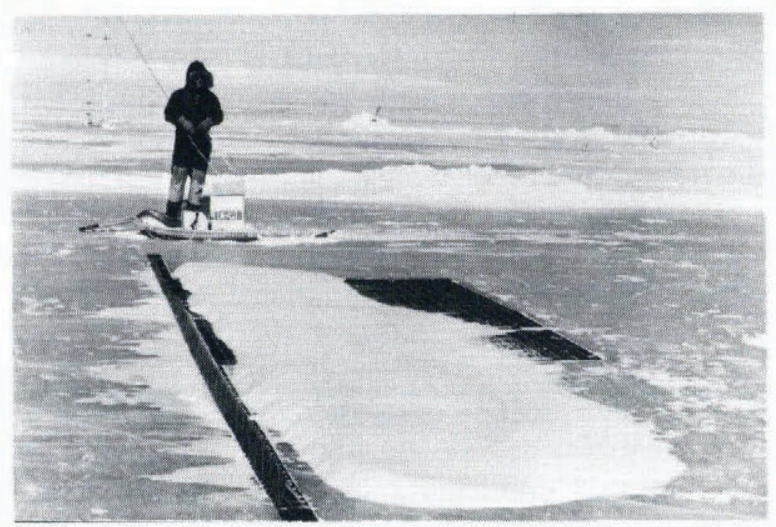

Fig. I. I/30 scale model snow fences on Diamond Lake, 30 January 1979. A portion of the Io $m$ wind-profile mast can be seen in the background. 
A I/30 scale model was also constructed of a terrain section at mile 253.4 on Wyoming's Interstate Highway 8o. This model was $23 \mathrm{~m}$ long in the direction of the wind, about $20 \mathrm{~m}$ wide, and was constructed from compacted snow. The surface was made as smooth as possible by troweling, and was stabilized by spraying the completed model lightly with a water and dye solution. Snow accumulation was measured both with and without snow fences, which were installed in the same relative locations as at the prototype site.

\section{Results}

\section{Wind-profile parameters}

As shown in Figures 2 and 3 , the wind-profile parameters $z_{0}$ and $u_{*}$ and their relationship to the ro $\mathrm{m}$ wind speed $\left(U_{\mathrm{I0}}\right)$, varied according to surface conditions. For bare ice, $z_{0}$ decreased with increasing shear velocity in approximate accord with Nikuradse's (Sutton, r953) equation for smooth flow:

$$
z_{0}=v / 9 u_{*}
$$

Using the criterion of Inequality (6b), flow over the ice surface would remain in the smooth regime up to $u_{*}=45 \mathrm{~cm} / \mathrm{s}$.

When the ice was more than $75 \%$ snow-covered, $z_{0}$ increased with $u_{*}$ for wind speeds above the threshold for snow movement, in a manner consistent with Owen's (1964) hypothesis. A regression model of the form

$$
z_{0}=A u_{*} \mathrm{~B} ; \quad u_{*} \geqslant u_{* \mathrm{i}},
$$

fitted to the data for $U_{10} \geqslant 8 \mathrm{~m} / \mathrm{s}$, gave $B=1.92 \pm 0.19$ and $r^{2}=0.59$. Since the $95 \%$ confidence interval, shown above, contains the value 2.0, and accepting Owen's argument that $z_{0} \propto u_{*}^{2}$, results from the experiment give

more than $75 \%$ snow cover:

$$
z_{0}=1.3509 \times 10^{-5} u_{*}^{2}, \quad U_{10} \geqslant 8 \mathrm{~m} / \mathrm{s},
$$

where $z_{0}$ is in $\mathrm{cm}$ and $u_{*}$ is in $\mathrm{cm} / \mathrm{s}$. Equation (10) implies a value for the constant $D$ in Equation (5) of 9.1. These results are compared in Table I with the author's analyses of data published by Liljequist (1957) and Budd and others (1966).

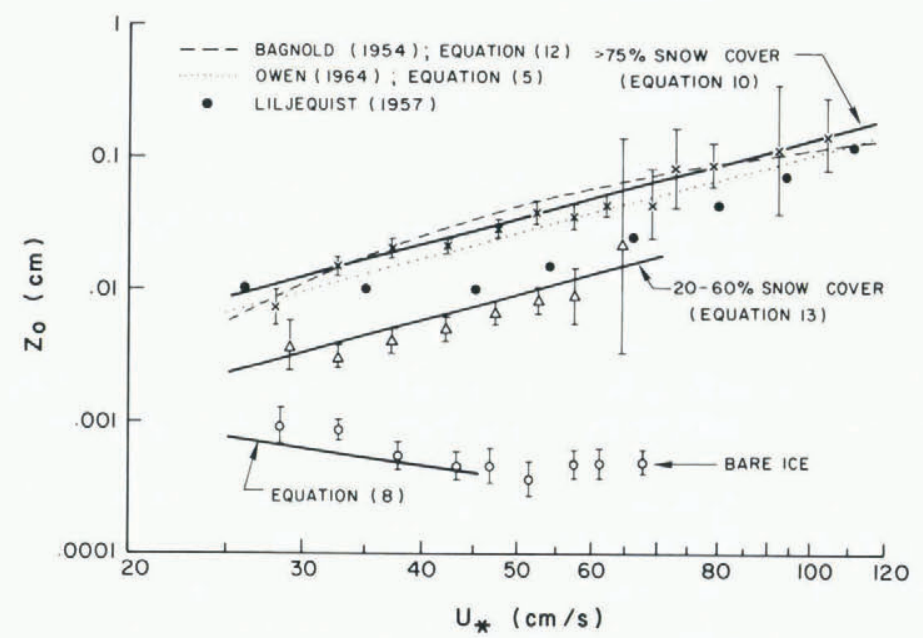

Fig. 2. Roughness height $z_{0}$ in Equation $(I)$ as a function of shear velocity $u_{*}$ for three categories of snow cover on Diamond Lake. Bars represent $95 \%$ confidence intervals about the geometric means of $z_{0}$ for $5 \mathrm{~cm} / \mathrm{s} u_{*}$ classes. Bagnold's (I954) equation is plotted with $k^{\prime}=0.30 \mathrm{~cm}$ and $u_{\mathrm{t}}=250 \mathrm{~cm} / \mathrm{s}$. 


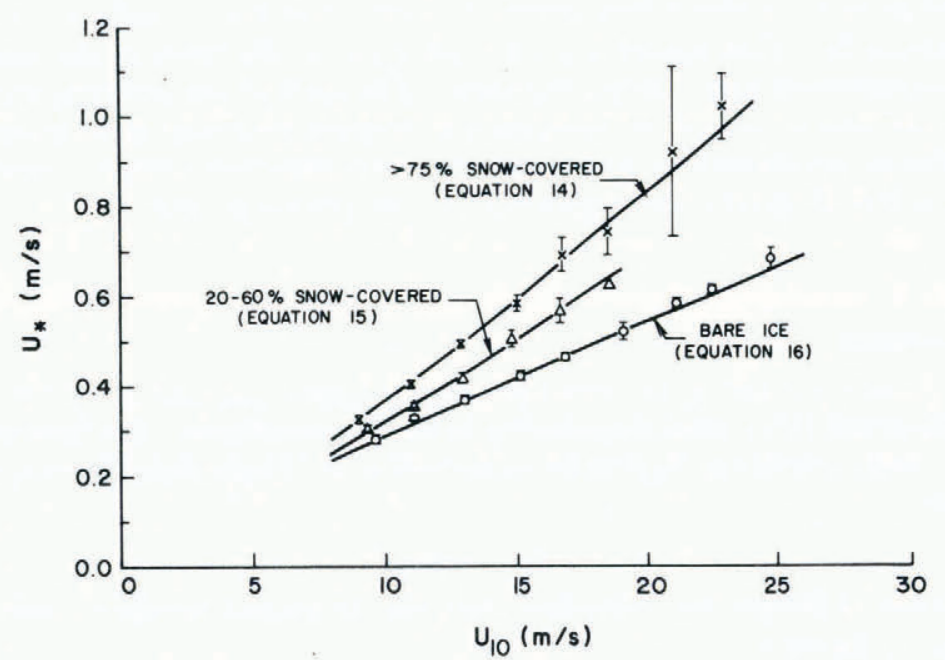

Fig. 3. Shear velocity $u_{*}$ as a function of $10 \mathrm{~m}$ wind speed, for three categories of snow cover on Diamond Lake. Bars show $95 \%$ confidence intervals about $u_{*}$ means for $2 \mathrm{~m} / \mathrm{s} U_{\mathrm{IO}}$ classes.

TABle I. Estimates fOR PARAMETERS IN EMPIRICAL RELATIONShIPS BETWEen $z_{0}, u_{*}$, AND $U_{\text {Io }} \geqslant 8 \mathrm{~m} / \mathrm{s}$

$\begin{array}{lcrccc} & A & D & A^{\prime} & B^{\prime} & n \\ \text { Present study } & & & & & \\ \quad \text { More than 75\% snow cover } & 1.3509 \times 10^{-5} & 9.1 & 0.024 & 1.18 & 279 \\ \text { 20-60\% snow cover } & 0.3626 \times 10^{-5} & 12.4 & 0.024 & 1.12 & 171 \\ \text { Bare ice } & - & - & 0.035 & 0.92 & \begin{array}{c}140 \\ \text { Liljequist (1957) }\end{array} \\ \text { Budd and others (1966) } & 1.5528 \times 10^{-5} & 8.7 & 0.017 & 1.30 & \text { (I class means) } \\ \text { Owen (1964) } & 0.6209 \times 10^{-5} & 11.0 & 0.025 & 1.14 & 129 \\ & 1.0536 \times 10^{-5} & 9.7 & 0.020 & 1.25 & \text { (from Equation (5)) }\end{array}$

$z_{0}=A u_{*}^{2}\left(z_{0}\right.$ in $\mathrm{cm}$ and $u_{*}$ in $\left.\mathrm{cm} / \mathrm{s}\right), D=-2.5 \ln (2 g A)$ and is the constant in Equation ( $\left.5 \mathrm{a}\right)$,

$u_{*}=A^{\prime} U_{10}{ }^{\prime}{ }^{\prime}\left(u_{*}\right.$ and $U_{10}$ in $\left.\mathrm{m} / \mathrm{s}\right)$, and $n$ is the number of wind profiles used in the analyses.

Kikuchi and Ishida (1976) found their wind profiles were better represented by Bagnold's (r954) equation:

$$
u=2.5 u_{*} \ln \left(z / k^{\prime}\right)+u_{t},
$$

where $k^{\prime}$ is the height of the apparent "focal point" for convergence of wind profiles in saltating flows, and $u_{t}$ is the wind speed at $z=k^{\prime}$. Solving Equation (I I) for $z$ at $u=0$ gives

$$
z_{0}=k^{\prime} \exp \left(-0.4 u_{t} / u_{*}\right) .
$$

For our data, $k^{\prime}$ was estimated to be $0.19 \mathrm{~cm}$ and $u_{t}=215 \mathrm{~cm} / \mathrm{s}\left(r^{2}=0.59\right)$, compared to Bagnold's values of $0.3 \mathrm{~cm}$ and $250 \mathrm{~cm} / \mathrm{s}$. Equation (I I) fits our data nearly as well as does Equation (9).

When the ice was only 25 to $60 \%$ covered with snow, $z_{0}$ also appeared to be related to $u_{*}{ }^{2}$, but with a different coefficient of proportionality, so that

$$
20-60 \% \text { snow cover: } z_{0}=0.3626 \times 10^{-5} u_{*}{ }^{2}, \quad U_{\text {I0 }} \geqslant 8 \mathrm{~m} / \mathrm{s},
$$

suggesting that saltation roughness is superimposed on that of the underlying surface. The existence of a smaller $z_{0}$ on partially snow-covered ice has important consequences for natural modeling, as indicated by Equation (4), allowing smaller models to be used. 
The relationship of $u_{*}$ to $U_{\text {I0 }}$ for $U_{\text {Io }} \geqslant 8 \mathrm{~m} / \mathrm{s}$, is shown in Figure 3 . The hypothesis that $u_{*}$ is linearly related to $U_{\mathrm{I0}}$ over bare ice, cannot be rejected at the $95 \%$ probability level, but curvature is significant for conditions of blowing snow. For $u_{*}$ and $U_{10}$ in m/s, and $U_{10} \geqslant 8 \mathrm{~m} / \mathrm{s}$,

more than $75 \%$ snow cover: $\quad u_{*}=0.0240 U_{10}{ }^{1.18}$,

$20-60 \%$ snow cover:

$$
\begin{aligned}
& u_{*}=0.024{ }^{\mathrm{I}} U_{10}{ }^{\mathrm{I} . \mathrm{I} 2}, \\
& u_{*}=0.0347 U_{10}{ }^{0.92} .
\end{aligned}
$$

bare ice:

The departure from linearity arises from the increase in saltation roughness as wind speed increases. Although this suggests $U / u_{*}$ is not exactly equal in model and prototype as required by Equation (4), the disparity is rather small. Comparisons with published data are given in Table I.

In summary, these results suggest that the similitude requirements of Equation (4) are closely approximated under natural conditions for the range of data of this study, supporting the hypothesis of self-similarity for wind profiles associated with blowing snow. Equations (Io) and (I4) can be used to determine prototype wind characteristics.

\section{Modeling trials}

Although we have conducted a variety of experiments with small-scale snow fences over the last three years, we will only present here examples of elementary experiments that test the natural similitude hypothesis and demonstrate application of scaling laws to outdoor modeling.

Maximum drift profiles which we have measured behind full-scale fences having heights of $\mathrm{x} .8,2.4,3.2$, and $3.8 \mathrm{~m}$ are plotted in Figure 4 . These data, collected over the last eight years from snow fences along Interstate Highway 80 in south-east Wyoming, prompted our interest in the natural scaling phenomenon.

A polynomial equation fitted to the full-scale lee-drift profile is

$$
\begin{aligned}
& y / H=0.20+0.377(x / H)-0.0472(x / H)^{2}+0.002329(x / H)^{3}- \\
&-5.392 \times 10^{-5}(x / H)^{4}+4.840 \times \mathrm{IO}^{-7}(x / H)^{5}, \quad x / H<30,
\end{aligned}
$$

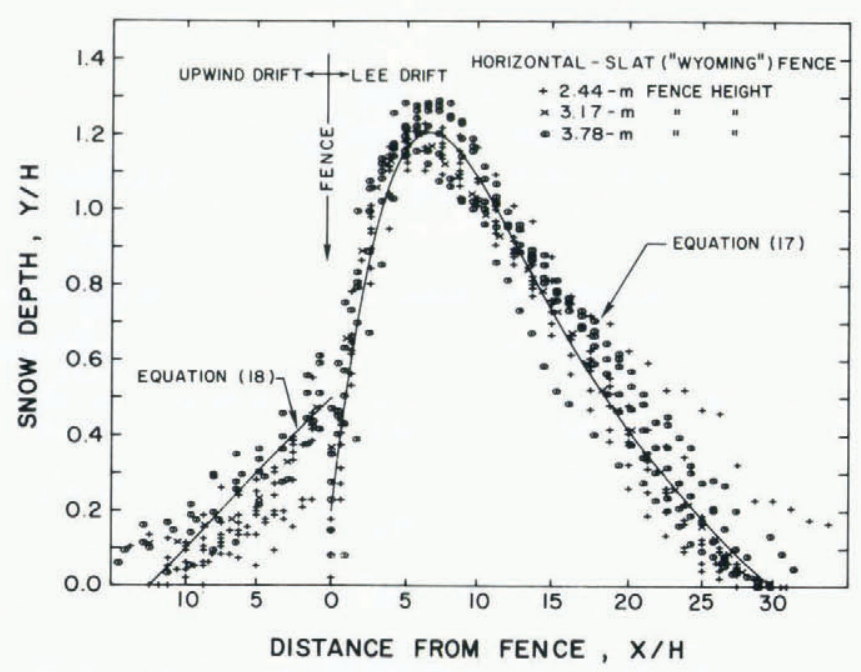

Fig. 4. Snow profile of drifts behind full-scale snow fences, at maximum accumulation. Data are from the Interstate Highway 80 snow-fence system between Laramie and Walcott, Wyoming. 
where $y$ is snow depth at distance $x$ from the fence, and $H$ is fence height. The up-wind drift is approximated by

$$
y / H=0.5-0.04(x / H), \quad x / H<\mathrm{I} 2.5 .
$$

Data for the 5.5 and $12.4 \mathrm{~cm}$ models on Diamond Lake are shown in Figure 5, together with the full-scale Equations (I 7 ) and (18). The model fences are both about $1 / 30$ of their prototype heights.

Surface conditions and wind-profile parameters measured during the model runs are shown in Table II, with prototype wind characteristics estimated from Equation (4). In general, relationships between measured wind-profile parameters are expected to depart from the averages represented by regression equations ((I0), (I3), (I4), and (I5)) because of sampling and measurement errors and natural variation. Different estimates for the prototype wind-profile characteristics are therefore obtained depending on whether the dimension ratio is equated to the $z_{0}$ or $u_{*}^{2}$ ratios.

For the 22 January model measurements, the drift profile is seen from Figure 5 to have roughly the same lee-drift geometry as described by Equation (I7) for full-scale drifts: maximum depth of $1.2 \mathrm{H}$ at $6 \mathrm{H}$ from the fence, maximum length of about $30 \mathrm{H}$, and crosssectional area of about $19 H^{2}$. Geometry of the windward drift is also quite similar in model and prototype, the primary exception being the depth of snow deposition at the fence.

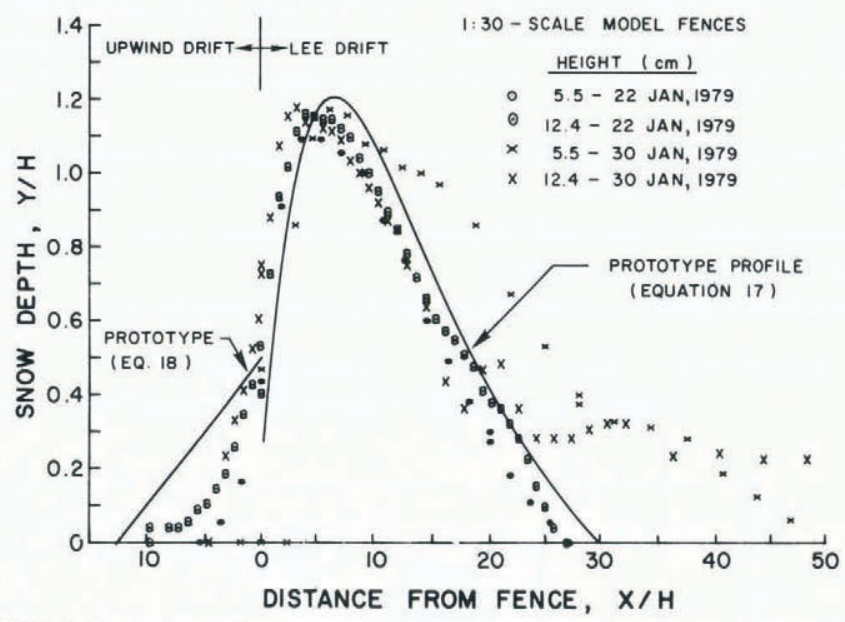

Fig. 5. Comparison of drifts behind I/30 scale model snow fences on lake ice, with the polynomial equation fitted to the full-scale data of Figure 4 .

TABLE II. WIND-PROFILE PARAMETERS FOR MODEL RUNS AND ESTIMATES FOR PROTOTYPE WIND

\begin{tabular}{|c|c|c|c|c|c|c|c|c|}
\hline \multirow[b]{2}{*}{ Date } & \multirow[b]{2}{*}{$\begin{array}{c}\text { Snow cover } \\
\%\end{array}$} & \multicolumn{3}{|c|}{ Profile during model runs } & \multirow{2}{*}{$\begin{array}{c}\text { Scaling } \\
\text { assumption }\end{array}$} & \multicolumn{3}{|c|}{ Estimated prototype profile* } \\
\hline & & $\begin{array}{c}z_{0} \\
\mathrm{~cm}\end{array}$ & $\begin{array}{c}u_{*} \\
\mathrm{~cm} / \mathrm{s}\end{array}$ & $\begin{array}{l}U_{\text {I0 }} \\
\mathrm{m} / \mathrm{s}\end{array}$ & & $\begin{array}{l}z_{0} \\
\mathrm{~cm}\end{array}$ & $u_{*}$ & $\begin{array}{l}U_{10} \\
\mathrm{~m} / \mathrm{s}\end{array}$ \\
\hline 22 January I979 & 80 & 0.005 & 23 & 7 & $\mathrm{II}_{+}^{\mathrm{I}}$ & $\begin{array}{l}0.150 \\
0.214^{(10)}\end{array}$ & $\begin{array}{l}105^{(10)} \\
126\end{array}$ & $\begin{array}{l}25^{(14)} \\
29^{(14)}\end{array}$ \\
\hline 30 January 1979 & 90 & 0.016 & 41 & 12 & IIt & $\begin{array}{l}0.480 \\
0.684^{(10)}\end{array}$ & $\begin{array}{l}188^{(10)} \\
225\end{array}$ & $\begin{array}{l}40^{(14)} \\
47^{(14)}\end{array}$ \\
\hline 9 February 1979 & 25 & 0.001 & 47 & 17 & $\underset{\mathrm{II}_{+}^{+}}{\mathrm{I}}$ & $\begin{array}{l}0.030 \\
0.892^{(10)}\end{array}$ & $\begin{array}{l}47^{(10)} \\
257\end{array}$ & $\begin{array}{l}12^{(14)} \\
5^{(14)}\end{array}$ \\
\hline
\end{tabular}

* Reference numbers of equations used for calculations are shown in parentheses.

$\dagger$ I: $\left(z_{0}\right)_{\mathrm{p}}=\left(z_{0}\right)_{\mathrm{m}}\left(L_{\mathrm{p}} / L_{\mathrm{m}}\right)$.

$\ddagger$ II: $\left(u_{*}\right)_{\mathrm{p}}=\left(u_{*}\right)_{\mathrm{m}}\left(L_{\mathrm{p}} / L_{\mathrm{m}}\right)^{\mathrm{l}}$. 
Representative stages in drift growth behind the $12.5 \mathrm{~cm}$ fence on 22 January are compared with full-scale drifts at approximately the same stages of growth in Figure 6. This comparison suggests that model similitude exists at all stages of deposition.

If air density, particle density, and bulk density of the deposited snow were identical in model and prototype, the time scale proposed by Kind (1976) would be

$$
\frac{t_{\mathrm{m}}}{t_{\mathrm{p}}}=\frac{L_{\mathrm{m}} / U_{\mathrm{m}}}{L_{\mathrm{p}} / U_{\mathrm{p}}}=\frac{L_{\mathrm{m}} / u_{* \mathrm{~m}}}{L_{\mathrm{p}} / u_{* \mathrm{p}}} .
$$

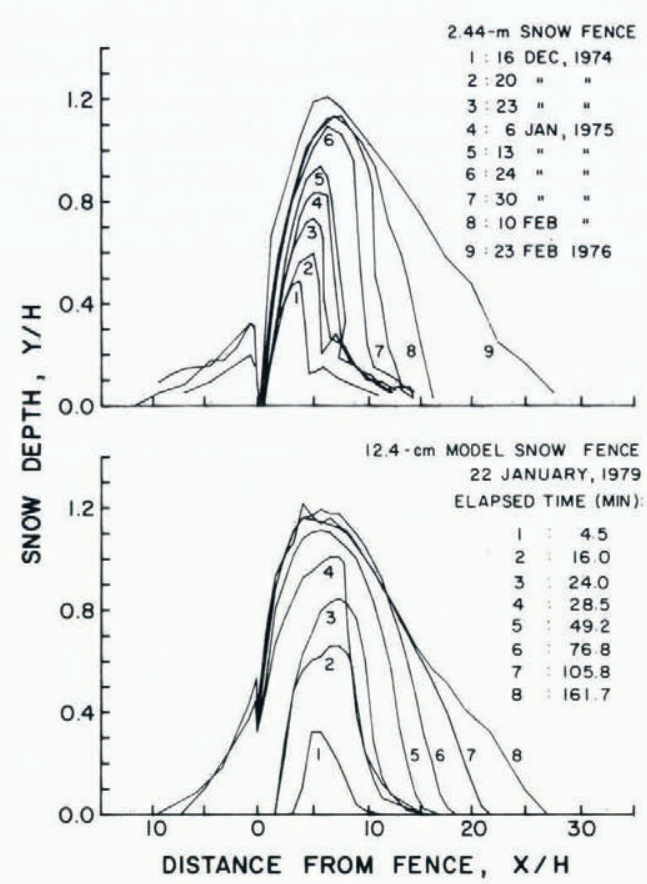

Fig. 6. Stages in snow accumulation behind a $2.44 \mathrm{~m}$ full-scale fence, and a $12.4 \mathrm{~cm}, \mathrm{I} / 30$ scale model simulating a $3.8 \mathrm{~m}$ structure.

Bulk density $\gamma$ of newly deposited snow varies with air temperature and humidity, size and shape of snow particles, wind speed, and depth of the deposited snow. The mean bulk density of the snow deposited behind the $12.4 \mathrm{~cm}$ model fence on 22 January was $100 \mathrm{~kg} / \mathrm{m}^{3}$. By comparison, mean bulk density of the drift formed behind a $3.8 \mathrm{~m}$ fence is typically about $450 \mathrm{~kg} / \mathrm{m}^{3}$ by the end of the accumulation season (Tabler, 1980 ). To account for this difference, Equation (19) can be rewritten as

$$
\frac{t_{\mathrm{m}}{ }^{\prime}}{t_{\mathrm{p}}{ }^{\prime}}=\frac{\gamma_{\mathrm{m}}}{\gamma_{\mathrm{p}}}\left(\frac{L_{\mathrm{m}} / u_{* \mathrm{~m}}}{L_{\mathrm{p}} / u_{* \mathrm{p}}}\right),
$$

where $t^{\prime}$ is the time required for equilibrium profiles to be attained.

For the 22 January example, $2.7 \mathrm{~h}$ were required for the $12.4 \mathrm{~cm}$ model to reach equilibrium. Using the values in Table II, the corresponding prototype time would be calculated from Equation (20) as 67 to $80 \mathrm{~h}$, which seems reasonable when compared with times calculated from the mass-transport equation given by Budd and others (ig66).

The model run on 30 January, also shown in Figure 5 and with conditions given in Table II, demonstrates profiles that are not in agreement with observed full-scale values. 
Winds of the magnitude estimated for the prototype (Table II) are seldom encountered at the sites where we have measured the full-scale drifts, and then only as infrequent gusts. We are therefore left with the question of whether or not drifts behind full-scale fences would attain these excessive proportions given persistent 40 to $50 \mathrm{~m} / \mathrm{s}$ winds and unlimited snow. This example demonstrates the need for restricting small-scale modeling to low wind-speeds, and preferably to ice less than $60 \%$ snow-covered if typical prototype winds are to be simulated.

A final example is that provided by the $1 / 30$ model of three rows of snow fence on $1 / 30$ scale model terrain, shown in Figure 7. This particular terrain example was selected for study because we have been measuring snow accumulation at the prototype site since 1971, and have observed the interesting terrain interaction where the uphill topography in front of the lead $1.8 \mathrm{~m}$ fence caused a much larger drift than would be expected on level terrain. As a consequence, during heavy snow years the second $(3.2 \mathrm{~m})$ fence is nearly buried, even though these two fences are spaced about $46 \mathrm{~m}$ apart. Another interesting feature at this site is the apparent inefficiency of the third $(3.8 \mathrm{~m})$ fence as indicated by its small drift and an excessive snow accumulation in the road cut.

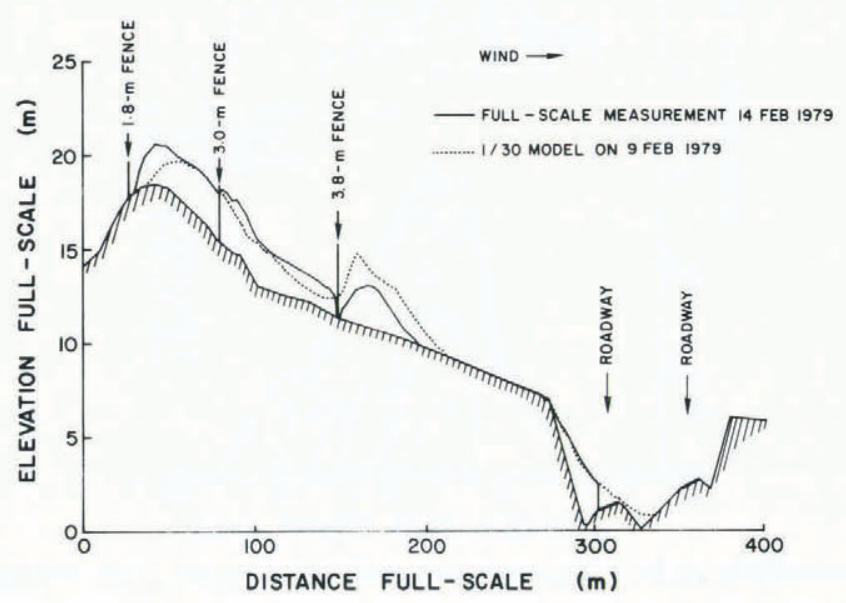

Fig. 7. Equilibrium drift profile for a I/3o scale model of cross-section at Mile 253.4, Interstate Highway 8o (Wyoming). Model terrain was constructed on lake ice from compacted snow. Full-scale measurements near the end of an unusually severe winter are shown for comparison.

The model drift is in general agreement with the prototype, predicting burial of the second fence, an abnormally small drift behind the third fence (about ro $H$ shorter than on level terrain), and essentially identical drift slopes in the road cut both with and without fences. The abrupt termination of the prototype drift at the edge of the roadway is the result of snow plows removing the drift. The slope of the snow-drift in the model cut also agrees with that predicted by an empirical regression method developed by Tabler (1975) for full-scale drifts. The primary disparity is that the top of the drift behind the lead fence in the model is substantially lower, and displaced further down-wind, than in the full-scale measurement.

It is doubtful whether the wind-speed profiles measured at the instrument mast were representative of this model site, because the model was about $100 \mathrm{~m}$ from the mast. There appeared to be less snow cover at the mast, and less blowing snow than at the model. The wind profile parameters (Table II) were more characteristic of bare ice than conditions usually encountered during typical model runs, and consequently the scaled prototype wind estimated from the $z_{0}$ ratios does not correspond to that derived from the $u_{*}{ }^{2}$ ratios. As a further 
complication, the $z_{0}$ measured over the partially snow-covered ice may not represent the effective $\left(z_{0}\right)_{\mathrm{m}}$ over the compacted snow surface of the model terrain.

Despite the fact that prototype winds cannot be specified for this example, there is little doubt that fence-terrain combinations can be successfully modeled under natural conditions, at scale ratios as small as $\mathrm{I} / 30$.

\section{Conclusion AND DISGussion}

Snow-drifts formed by fences appear to be scaled in proportion to fence height over a height range of nearly two orders of magnitude. It is suggested that requirements for dynamic similarity of the flow fields are satisfied over a period of time because $z_{0}$ varies approximately as $u_{*}{ }^{2}$ in saltating flows. Satisfaction of requirements for scaling motion of snow particles is less certain, although natural sorting may effectively scale saltating particles over a restricted range of wind speeds. Drifts formed by $\mathrm{r} / 30$ scale models, having heights as small as $5 \mathrm{~cm}$, are proportionately scaled to those behind their full-scale prototypes at all stages of drift growth. This observation, together with the reasonable time required for equilibrium drifts to be attained behind the models, suggests snow concentration profiles may also exhibit selfsimilarity. The natural scaling of snow-drifts may, in itself, only reflect the dominant role of saltation in the deposition process.

If typical prototype winds are to be simulated using a model scale as small as $1 / 30$, the experiments must be done on partially snow-covered lake ice or a surface of comparable roughness, with winds near the threshold for snow movement. At stronger wind speeds, corresponding to scaled prototype $U_{10}$ of the order of $40 \mathrm{~m} / \mathrm{s}$, model drifts are significantly longer than observed in the full scale at lower wind speeds. This suggests the need for simultaneous wind-profile measurements during outdoor modeling experiments if results are to be properly interpreted with respect to prototype conditions.

The required model scale is determined by the prototype wind speeds to be modeled, and I/30 appears to be near the practical minimum. An obvious disadvantage of outdoor modeling is the variability of natural conditions. If conditions change appreciably during the course of an experiment, the study must be repeated. Small models are preferable to larger ones in this respect, since less time is required to attain equilibrium. Although it is not known if natural scaling requirements could be met with smaller models, our experience has shown that $5 \mathrm{~cm}$ is near the minimum model height considering the precision with which the drifts can be measured and the rate of accumulation relative to the time required for measurement. Near to the threshold wind speeds, about $2.5 \mathrm{~h}$ are required for a $12.4 \mathrm{~cm}$ snow fence model to reach equilibrium as compared to $0.9 \mathrm{~h}$ for a $5.5 \mathrm{~cm}$ model.

Results from this study also demonstrate that terrain and snow-fence-terrain combinations can be successfully modeled at scales as small as $\mathrm{I} / 30$, using compacted snow as a construction material.

Natural modeling is a promising technique with which to solve a variety of scientific and practical problems that cannot be practically resolved in full-scale experiments or conventional wind-tunnel or flume studies.

\section{Acknowledgements}

The research reported here was supported in part by the Surface Environment and Mining (SEAM) program, USDA Forest Service. The author gratefully acknowledges the assistance of Dr R. A. Schmidt in the design of instrumentation and collection of field data, and his many helpful suggestions throughout the study. The author is also indebted to research technicians Robert L. Jairell and David L. Pluth for their invaluable assistance in the demanding field work.

This paper is respectfully dedicated to Dr Uwe Radok, in recognition of his inspiring scientific and humanistic contributions. 


\section{REFERENCES}

Bagnold, R. A. I94I. The physics of blown sand and desert dunes. London, Methuen and Co. Ltd. [Reprinted with minor corrections, 1954.]

Budd, W. F. 1966. The drifting of nonuniform snow particles. (In Rubin, M. J., ed. Studies in Antarctic meteorology. Washington, D.C., American Geophysical Union, p. 59-70. (Antarctic Research Series, Vol. 9.))

Budd, W. F., and others. I966. The Byrd snow drift project: outline and basic results, by W. F. Budd, [W.] R. [J.] Dingle, and U. Radok. (In Rubin, M. J., ed. Studies in Antarctic meteorology. Washington, D.C., American Geophysical Union, p. 7 I-134. (Antarctic Research Series, Vol. 9.))

Calkins, D. J. 1975. Simulated snowdrift patterns. U.S. Cold Regions Research and Engineering Laboratory. Special Report 219.

Dyunin, A. K. r954. Tverdyi raskhod snegovetrovogo potoka [Solid flux of snow-bearing air flow]. Trudy Transportno-Energeticheskogo Instituta, Tom 4, p. 71-88. [English translation: Canada. National Research Council. Technical Translation $1102,1963$.

Dyunin, A. K. 1967. Osnovnyye usloviya aerodinamicheskogo modelirovaniya v prikladnoy glyatsiologii [Basic requirements of aerodynamic models in applied glaciology]. (In Sulakvelidze, G. K., and Dolov, M. A., ed. Fizika snega, snezhnyye laviny, i ledniki. Trudy Vysokogornogo Geofizicheskogo Instituta, Vyp. 12, p. 147-52. [English translation in Sulakvelidze, G. K., and Dolov, M. A., ed. Physics of snow, avalanches, and glaciers. Translated from Russian. New Delhi, Indian National Scientific Documentation Centre for the U.S. Dept. of Agriculture, Forest Service, and the National Science Foundation, Washington, D.C., 1973, p. 220-29.]

Holt, M. I961. Dimensional analysis. (In Streeter, V. L., ed. Handbook of fluid dynamics. New York, McGraw-Hill Book Co., Inc., p. $15^{-1-15-25 .)}$

Iversen, J. D. 1979. Drifting snow similitude. Fournal of the Hydraulics Division, American Society of Civil Engineers, Vol. 105, No. HY6, p. 737-53.

Iversen, J. D. I980. Drifting-snow similitude-transport-rate and roughness modeling. Fournal of Glaciology, Vol. 26, No. 94, p. 393-403.

Kikuchi, T., and Ishida, T. I976. Chifubuki-ji no sodo no zōka ni tsuite [A note on the increase of roughness during drifting of snow]. Teion-kagaku: Low Temperature Science, Ser. A, [No.] 34, p. 87-9i.

Kind, R. J. 1976. A critical examination of the requirements for model simulation of wind-induced erosion/ deposition phenomena such as snow drifting. Atmospheric Environment, Vol. 10, No. 3, p. 219-27.

Kobayashi, D. 1970. Jifubuki no hassei to hattatsu [Generation and development of drifting snow]. Teionkagaku: Low Temperature Science, Ser. A, [No.] 28, p. 141-46.

Langhaar, H. L. r951. Dimensional analysis and theory of models. New York, John Wiley and Sons, Inc.

Liljequist, G. H. 1957. Energy exchange of an Antarctic snow-field. Wind structure in the low layer (Maudheim, $\left.71^{\circ} \mathrm{o}^{\prime} \mathrm{S}, 10^{\circ} 56^{\prime} \mathrm{W}\right)$. Norwegian-British-Swedish Antarctic Expedition, 1949-52. Scientific Results, Vol. 2, Pt. IC.

Mellor, M. 1965. Blowing snow. U.S. Cold Regions Research and Engineering Laboratory. Cold regions science and engineering. Hanover, N.H., Pt. III, Sect. A3c.

Odar, F. 1965. Simulation of drifting snow. U.S. Cold Regions Research and Engineering Laboratory. Research Report 174 .

Owen, P. R. 1964. Saltation of uniform grains in air. Journal of Fluid Mechanics, Vol. 20, Pt. 2, p. 225-42

Radok, U. 1968. Deposition and erosion of snow by the wind. U.S. Cold Regions Research and Engineering Laboratory. Research Report 230.

Schmidt, R. A. 1980. Threshold wind-speeds and elastic impact in snow transport. Fournal of Glaciology, Vol. 26, No. 94 , p. $453-67$.

Stearns, C. R. I 970 . Determining surface roughness and displacement height. Boundary-layer Meteorology, Vol. I, No. I, p. IO2-II.

Sutton, O. G. 1953. Micrometeorology. New York, McGraw-Hill Book Co., Inc.

Tabler, R. D. 1974. New engineering criteria for snow fence systems. Transportation Research Record (Washington D.C.), 506 , p. $65-78$.

Tabler, R. D. 1975. Predicting profiles of snowdrifts in topographic catchments. Proceedings of the Western Snow Conference, 43rd annual meeting, p. 87-97.

Tabler, R. D. 1980 . Geometry and density of drifts formed by snow fences. Fournal of Glaciology, Vol. 26, No. 94, p. 405-19.

Vennard, J. K. 1974. Elementary fluid mechanics. Third edition. New York, John Wiley and Sons, Inc.

White, B. R., and Schulz, J. C. 1977. Magnus effect in saltation. Fournal of Fluid Mechanics, Vol. 81, Pt. 3, p. $497-512$.

Wuebben, J. L. 1978. A hydraulic model investigation of drifting snow. U.S. Cold Regions Research and Engineering Laboratory. Report 78-16.

Zingg, A. W. 1953. Wind-tunnel studies of the movement of sedimentary material. Proceedings of the fifth Hydraulics Conference, June 9-11, 1952, arranged by the Iowa Institute of Hydraulic Research, State University of Iowa, p. I $11-35$. 